November 2014

\title{
My Share of the Sky: Review 2
}

Alan Hall

Falling Tree Productions

Follow this and additional works at: http://ro.uow.edu.au/rdr

Part of the Audio Arts and Acoustics Commons, Digital Humanities Commons, European Languages and Societies Commons, and the Radio Commons

\section{Recommended Citation}

Hall, Alan, My Share of the Sky: Review 2, RadioDoc Review, 1(2), 2014. doi:10.14453/rdr.v1i2.9 


\title{
My Share of the Sky: Review 2
}

\begin{abstract}
This documentary by the celebrated Danish producer Rikke Houd, in collaboration with Iranian journalist Sheida Jahanbin, is a work of art. It is also a powerful piece of documentary journalism that measures the pulse of a young couple's emigration from Iran and their attempts to settle in Norway. The narration by Sheida Jahanbin, our guide to establishing a new life as an asylum seeker, is lent a profound dimension by being choreographed in a sophisticated 'hocketing' with the voiced-over translation, which acts as Sheida's Norwegian voice. This is an inspired device, which also serves as a metaphor in a story about communication, translation and transition. This documentary communicates both the circumstances of how a young couple escapes the horrors of imprisonment, suffering the anguish of exile and difficulties of assimilation, and, remarkably, it conveys the sense of how it feels to endure these trials. It's both a map of what has to be gone through and a poetic reflection on that migration.

There are countless potential narratives in this documentary - relating to history, poetry, activism, social care, personal dislocation - but the achievement of My Share of the Sky is to fulfil all of them. And more. Memory and dream or nightmare carry as much weight as reportage. A yearning for expression saturates this documentary, as is brilliantly encoded into every detail of the production. There is at work here a deeply empathetic intelligence that measures 'how' and 'why' as accurately as 'what'. Through an exemplary use of the unique palette available to the radio feature maker, $M y$ Share of the Sky demonstrates how fact and feeling, journalism and art, the everyday and the elevated can dance together in a profound expressive form. The program was a finalist in the Prix Europa 2012.
\end{abstract}

DOWNLOAD FULL REVIEW (2,200 words) AND EMBEDDED AUDIO CLIPS at 'Download' icon top right of page.

\section{Keywords}

asylum seeker, Iran, Norway, radio documentary, hocket 


\section{My Share of the Sky}

Producers: Sheida Jahanbin and Rikke Houd, NRK (Norway 2011). 41.20mins. Editing and sound: Rikke Houd. Mix and final Editing: Erki Halvorsen.

NRK consultant: Kjetil Saugestad. Norwegian voice: Annette Hobson. Translation: Eric Scobie.

\section{Reviewer: Alan Hall}

This documentary by the celebrated - and famously modest - Danish producer Rikke Houd, in collaboration with Iranian journalist Sheida Jahanbin, is a work of art. From the opening throat clearance to the final words, every scene, utterance, breath and sound - is finely weighed for its aesthetic, as much as its emotional or informational, effect. And this work of radio art is also a powerful piece of documentary journalism that measures the pulse of a young couple's emigration from Iran and their attempts to settle in Norway. The ambition of $M y$ Share of the Sky in both these dimensions sets a challenge to listeners inclined to favour either fact over feeling or vice versa in their radio productions. And its dual function as current affairs investigation and poetic portrait possibly explains why the programme hasn't quite had the critical acclaim this reviewer feels it is due.

Unusually for a Scandinavian production, the story unfolds as a montage of sound, combining fragments of audio diary with a series of scenes and moments of reflection. Our narrator isn't sat sedentary in a studio but is active in the scenes. The narration by Sheida Jahanbin, our guide to establishing a new life as an asylum seeker, is lent a profound dimension by being choreographed in a sophisticated 'hocketing' with the voiced-over translation, which acts as Sheida's Norwegian voice. This is an inspired device. On a practical level, it solves the problem of managing the narrator's fledgling command of Norwegian and the documentary's multiple languages - Farsi, English, Norwegian, DanishNorwegian. But more than this, it serves as a metaphor in a story about communication, translation and transition. The Translator (Rikke herself) retains Sheida's first person and delivers words and ideas that haven't been heard in the original language and, inversely, omits some details that might be picked up in 
English or Norwegian. It nobly resists pedantry. This is not only very clever. It changes the relationship of the listener to the story. No longer are we being addressed as outsiders, but we become witnesses in the scenes, part of the narrative fabric. Our position is alongside Sheida and Madyar, at their shoulder, in a dizzying cascade of experiences, emotions and scenes. And the situation of the protagonists' migration from once place to another, between cultures and different languages, becomes more than a literal representation of fact. It's the heart of the entire documentary. Everything is in transition and needs to be given voice - between countries and, people, journalism and poetry, memory and everyday reality, waking and sleep.

As Sheida says, "'I have no history here, no memory, no connection, no language."' And the Translator doesn't translate this line, but rather amplifies the thought: 'II receive letters, but I don't know what they say. I need assistance for even the simplest things'"'.

\section{Audio Clip: No History}

Sheida: I have no history here, no memory, no connection, no language.

Translator: I receive letters, but I don't know what they say. I need assistance for even the simplest things.

Small problems become big.

This documentary communicates both the circumstances of how a young couple escapes the horrors of imprisonment, suffering the anguish of exile and difficulties of assimilation, and, remarkably, it conveys the sense of how it feels to endure these trials. It's both a map of what has to be gone through and a poetic reflection on that migration.

For a production that attains at its centre a feeling tone of gentle concern for the couple, a yearning for peace and a respectful intimacy, it is enormously busy and quickly moving. Scene tumbles upon scene as we move through the experiences of attending a language course, having a medical check-up, phoning home, dealing with social services, visiting local sights and being quietly reflective at home, haunted by memory and nightmare. This kaleidoscope of activity achieves the impression of wholeness - it's a mosaic where the busy-ness of the tiny 22details is lost within the broader, calmer, more complete picture. And the transitions between scenes are achieved by the subtlest of connectors - a clunking door, a rattling key, a mobile ringtone - or else by a piece of music, a gentle shift in atmosphere/actuality- dissolving time, traversing territory and propelling us ever more closely into the lived experience of two strangers whose lives we come to share. There is nothing noisy in this documentary. It's testament to the idea that the surest way to get attention is to lower your voice. 
Narratively, it's simple, but a kind of simplicity that involves refined and elaborate decision-making. We follow Sheida as she goes through - and passes - a language course, interspersed with extracts from her diary and complementary scenes depicting the mundane nature of her daily existence. She's a modest, compelling character, with a poetic turn of phrase and a warmly appealing way of interacting with officials, neighbours and strangers. Her partner, Madyar, is a more shadowy figure, lost still in memories of Iran and jail and that glimpse through the cell window of a 'share of the sky'

\section{Audio clip: Meeting Madyar}

Sheida: (Farsi)

Sheida (translates): Madyar, do you remember the first time we met, at University? Madyar : (Farsi)

Translator: Yes, I remember. It was on November 1st 2004. An hour after saying goodbye to you I was arrested.

Madyar : (Farsi)

Sheida: I remember that day too, every moment.

We met by the bench in the university garden.

Translator: The garden was full of people, but I didn't pay attention to anyone else. We were our own tiny universe of brilliant suns, stars and moons.

S: You were wearing a light blue denim shirt.

We talked and talked.

I enjoyed looking into your eyes.

You asked me a lot of questions about politics.

I just smiled. I wanted to kiss you.

Translator: I promised to meet you the next day and waited by the bench, but you never came. I felt hurt and sad. Two weeks passed. Finally I asked one of your friends, he told me you had been arrested.

Their back-story blocks the sun out from their new lives. One senses that the skies are low and heavy, the decor in offices and apartments drab and grey. This is suggested partly through the choice of music, partly through the positioning of microphones and tone of voice. There's an unavoidable sadness and sense of isolation. They are prescribed vitamins to counter the lack of sun, typical of a Norwegian winter. But their emotional and psychological condition cannot be quite so readily treated. 'I have just Madyar, but he's alone too,' Sheida says with Christmas approaching. For Madyar, even sleep is invaded by the dark memories of his former life and the dream that shapes his ambitions. 


\section{Audio Clip: Prison Dream}

Madyar: (Farsi) This is the dream that always woke me up in my cell Translator: It was a long, bad night. One of many nights with torture.

M: (Farsi) This first week in prison I promised myself...

Translator: They forced me to eat shit. That night in prison I made a promise to myself. M: (Farsi)...I promised myself if I would ever get out of this prison I would spend the rest of my life defending those that are still not free.

Translator: That if I ever survived this prison, I would spend the rest of my life defending those that are still not free.

Sheida: Madyar, you are always in front of your PC, your eyes have started hurting. Always in contact with the pain of Iran. The prisoners and their family.

Translator: The stories of torture, executions, humiliations.

Telephones every day, voices from a mad world far away from Vestli. Sometimes I need fresh air, sun and go out and leave this mad world, but you remain indoors writing and writing.

S: Sometimes I think your work is more important for you than your life.

There are countless potential narratives in this documentary - relating to history, poetry, activism, social care, personal dislocation - but the achievement of $M y$ Share of the Sky is to fulfil all of them. And more. Memory and dream or nightmare carry as much weight as reportage, especially Madyar's bad dreams of the angry doll with no mouth. And that image encapsulates so much. It refers to the literal desire to keep one's mouth shut, having been made to eat shit in prison, but it also resonates deeply with the documentary's central theme of communication and what is lost in translation.

Eventually, light does creep into the frame, largely as a consequence of Sheida's determinedly cheerful attitude not to be lost in shadows. She finds connections with neighbours, with old folks and, via the memory of her father's bird shop, with music. A certain joy begins to seem possible with the old man 'tra-la-la-ing' and the arrival of Nina, a Norwegian volunteer, who, tellingly, brings with her the possibility of musical collaboration. Yet, a mournfulness remains, at the impossibility of communication

\section{Audio Clip: Telling Nina}

Translator: I wanted to tell Nina that my father used to sing with me.

That I like the white and yellow flowers that bloom in winter and fill the air in Tehran with their citrus scent.

That I like to drive in my sister's car and listen to loud music.

That I like to look through Grandma's old photo albums and feel my mother comforting me when I'm sad.

I want to tell her that I cannot return to Iran. Iran will not even accept my body when I die. I want to tell Nina all this. 
A yearning for expression saturates this documentary, as is brilliantly encoded into every detail of the production. The surface of the narrative follows Sheida and Madyar's pursuit of their studies in order to be able to connect with people and to communicate their fears and hopes. In a darker counterpoint, their colleague Farzad, still in Iran, finds a voice for all the terrible suffering he's been through in poetry.

\section{Audio Clip: Farzad}

(At home in apartment)

Farzad: (Farsi) Ok. The name of this poem is "Night, whipping, torture"

Sheida: Farzad called us from prison. He is a poet and a friend.

Translator: He used to work as a schoolteacher in Kurdistan. He reads a poem to Madyar.

F: (reading poem in Farsi)

S: It was night,

without moon,

without stars, without sky,

even without night,

with walls.

F: (Farsi)

Translator: The man who entered ordered me to blindfold myself.

F: (Farsi)

Translator: He gave me handcuffs and ordered me to follow.

S: At that time I hummed a poem.

The poem is:

F: (reading poem in Farsi)

S: God, where am I in the world?

F: (reading poem in Farsi)

Translator: At the sound of the whip I left for another world.

Where the humans' concern was to save Australia's lizards.

F: (reading poem in Farsi)

S: But here...here...oh...

F: (reading poem in Farsi)

Translator: With each lash I returned to the past.

To Genghis Khan's time.

But pain has no end.

F: (Farsi)

Translator: I lost conscience and after several hours, I returned to the world again and the floor of my cell.

F: (Farsi)

Translator: Like a newborn child I began to cry and again a poem came to me:

F: (reading poem in Farsi)

Translator: I saw a child being born and therefore I know that the first crying is the first sign of life

And tomorrow l'll hear knocking on the door...again and again...and again....

F: (reading poem in Farsi) 
And, remarkably, amid the sorrow and alienation, Sheida and Madyar not only progress in their struggle to build new lives, but they also find laughter, once again, as they practise their Norwegian - 'Jeg husker'. I remember - and successfully complete their language course. That triumph is immediately off-set with news of Farzad's execution. Shadows will remain. And this, I feel, is the tremendous achievement of this production: it conveys an authentic account not just of what these young people go through but enables us to share, almost viscerally, how their experiences impact upon them. There is at work here a deeply empathetic intelligence that measures 'how' and 'why' as accurately as 'what'. Through an exemplary use of the unique palette available to the radio feature-maker, My Share of the Sky demonstrates how fact and feeling, journalism and art, the everyday and the elevated can dance together in a profound expressive form.

And as for Sheida, she's now passed the highest language level and has made Oslo her home.

\section{AUDIO of PROGRAM AND FULL TRANSCRIPT}

URL: http://www.fallingtree.co.uk/listen/curated_my_share_of_the_sky 
ALAN HALL has been a radio producer since 1990 and has built a reputation for long-form documentaries, music features and innovative formats (Between the Ears, Short Cuts and The Design Dimension among them). Before 1998 he worked as a staff producer at the BBC but has since been independent, establishing Falling Tree Productions as one of the world's leading radio production companies. His - and the company's - programs have received numerous awards from the Prix Italia, Prix Europa, Third Coast Festival, Radio Academy and elsewhere. Alan is also in demand as a writer and speaker about storytelling in sound.

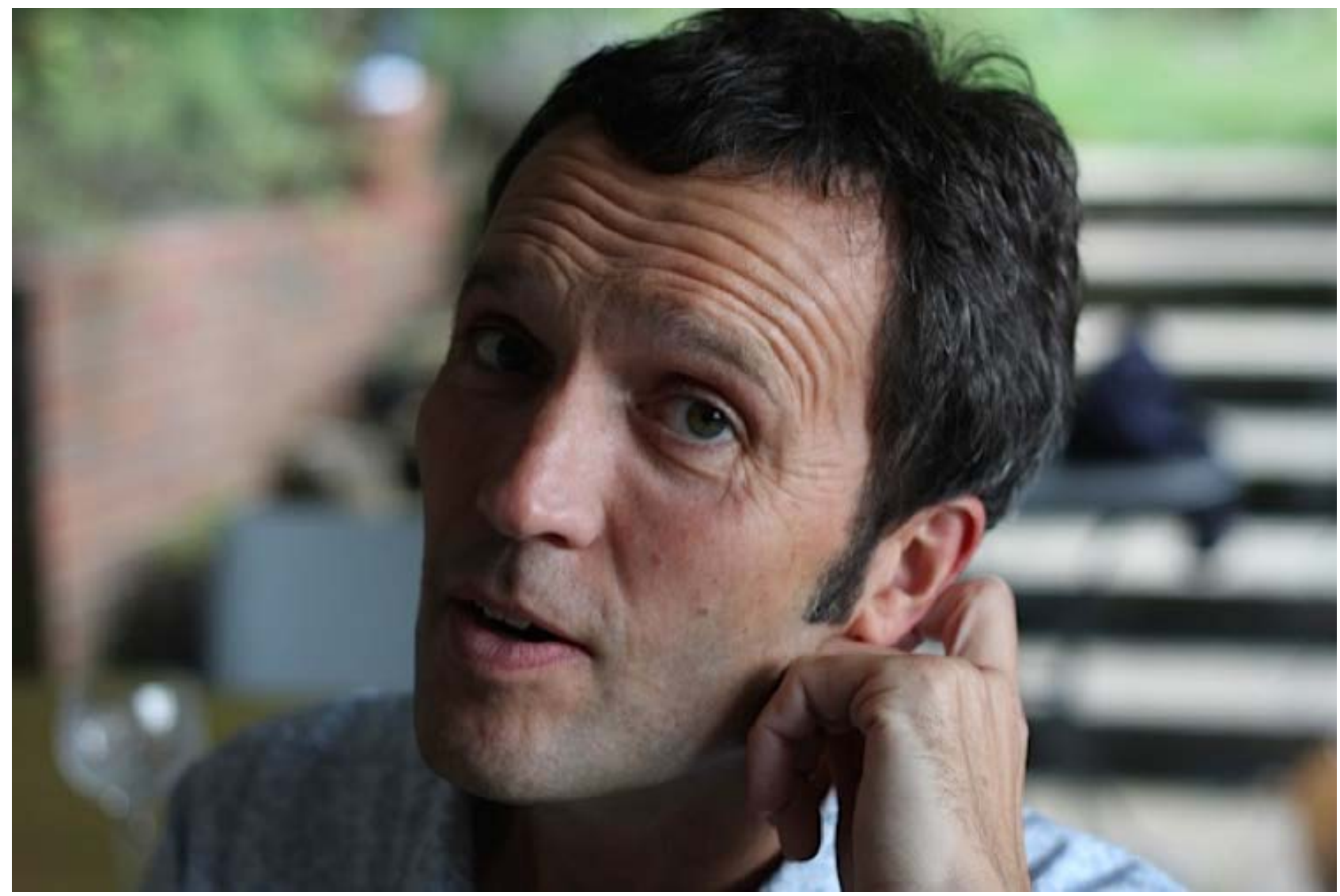

